\title{
COMPARISON BY MORPHOLOGICAL CHARACTERS OF TWO NEW VARIETIES OF WINTER WHEAT PLANTS
}

\author{
Nicolaie Ionescu ${ }^{1^{*}}$, Bogdan Alexandru Guță ${ }^{\mathbf{2}}$, Cristina Ghiorghe ${ }^{\mathbf{1}}$, Oana Badea ${ }^{\mathbf{1}}$, \\ Diana Popescu ${ }^{1}$, Cătălin Dinuță ${ }^{1}$, Mariana Nicolaie ${ }^{1}$, \\ Magdalena Podea $^{1}$, Robert Gheorghe ${ }^{1}$ \\ ${ }^{1}$ Agricultural Research and Development Station Piteşti, \\ Piteşti-Slatina road km. 5, 117030, Piteşti, România \\ ${ }^{2}$ Syngenta Agro SRL
}

\begin{abstract}
Some current studies on morphological, biochemical, molecular of wheat plants could be used in the progress of varieties' improvement, adapted to current requirements (Black and Halmer, 2006). Board genetic dowry and wheat crop conditions usually lead to characteristic expression of plant morphology. In winter wheat, both in the case of a Phyton and a Foxyl varieties, some new directions have been found, which have recently been improved. Thus, in the two variety comparison, the straw was shorter in the hybrid with $6 \mathrm{~cm}$. The basal internode (the third of top) was $1 \mathrm{~cm}$ longer in the variety, with its thickness between the same limits in both forms (3.1-3.2 mm). The sub-apical internode measured less $1 \mathrm{~cm}$ in the Phyton, and the apical internode was shorter by $2-4 \mathrm{~cm}$ in the Foxyl. The ear had the longest in the Foxyl, but the weight of the spikes was similar (ears were dominated by 2.1-2.3 g). Each spikes contained 16-17 spikelets in both forms. Spikelet had an external glume and inferior palea shorter to the Phyton, and the awn was longer 2-3 cm in the sema variety. The medium spike contained 15-16 more grains in the Phyton, and the total mass of the grains in a spike weighed more with $0.2 \mathrm{~g}$ in the same variety. The grains were longer by about $1.0 \mathrm{~mm}$ and the thickness was 0.4-0.5 mm more both in the Foxyl variety. The mass of thousand grains in smaller limits was at Phyton (33-36 g), while the Foxyl had the much larger grain weight $(45-51 \mathrm{~g})$. Between the morphological characters of the plants, significant positive correlations were obtained only between the components of the spikes in both forms. Un important links were obtained between the characters of the straw with the other plant elements in the Phyton and significant linkages under the same conditions in the Foxyl. Both forms of winter wheat demonstrated through the morphological characters manifested, good zonal adaptability.
\end{abstract}

Keywords: grains, spikes(ears), spikelets, variability, wheat

\section{INTRODUCTION}

Being known for a long time, the wheat [Triticum aestivum (L.) Thell ssp. vulgare (Will.) MK] is between the most important cereal crops (maize, rice, barley) (Hopf and Zohary, 2000; Bonjean and William, 2001). The plant have additional genes for its resistance to cold, required under temperate climates (Brenchley et al., 2012; Li et al., 2014) and recently to the new conditions of climate changes. By its high adaptability, wheat grows in a multitude of cultural conditions, on all continents. The cultivation of wheat is properly for the production of grains. The grains have a lot 
of nutrients (Sabelli and Larkins, 2009) considered diverse and balanced, especially in human nutrition. In the recent years, the plant has evolved in different characters (Tester and Langridge, 2010), adapted to the new condition, including to the climate changes. From genetically point of view wheat is considered to be like diverse between the cereals (Bray and West, 2005). The present varieties have hexaploid genome $2 n=6 x(6 \times 7)=42$. The forms analyzed in the paper belong to the variety of erythrospermum Körn., with white spikes/ears, awns, rough glume and red grain (Caligari and Brandham, 2001). Both contain the modern RHt gene which determines strain/ short straw, suitable for intense crop elements: high level of fertilization, mechanized harvesting. The consequence is that new varieties can be very productive and with a relative resistance to the new climate changes.

In general, from botanical point of view, the plant's inflorescence is a $4-18 \mathrm{~cm}$ long distich spike, with sessile spikelets, each one in zigzag over rachis. The spikelets is $10-15 \mathrm{~mm}$ long, being laterally compressed, with two glume and several flowers. Glumes have a short tooth, and the external one with a 3-5 cm awn. Each flower has two membranes: palea and lemma. Depending on variety, the lemma expands in the form of awn, or as a hood. The grain (caryopses type) is ellipsoidal, with a central channel on one side. The grain has 4-12 mm long and 1.5-4.0 mm thick. The mass of one thousand grains (MTG) is between 15-60 g (Black and Halmer, 2006). The plant generally forms stalks with heights between 50(60) and 140(150) cm.

The research carried out to observe the variation of some wheat plant characters in the two forms included: i) the strain by the total length of the straw, the length and thickness of the basic internode (third top), the length of the sub-apical internode and the length of the apical internode, ii) the length and weight of the spike, iii) the number of spikelets/ ear, the length of the external glume the length of the lower palea (lemma) and the length of the awns, iv) the number of grains/ ear, their weight, the mass of a thousand grains (MTG) and the grains dimensions (length and thickness).

\section{MATERIALS AND METHODS}

Variants heve been cultivated in recent years with the Phyton and the Foxyl varieties, both with relatively close morphological characteristics. The experiment was set up by the block design (method), with variants of $25 \mathrm{~m}^{2}$ in four replicates. The technology used was the one recommended by the resort. At the full maturity, 25 plants/ stems from each replicates (total 100) were randomly picked and brought to the laboratory. The 100 strains were measured and determined: the total length of the straw, the length and thickness of the basic internode, the length of the sub-apical internode, the length of the apical internode, the length and the weight of the spike, the number of spikelets in the spike, the length of the awn, the number of grains in a spike and their weight, the mass of a thousand grains (MTG), and the size of the grains: the length and thickness.

The morphological characters obtained were analyzed by the histogram method (frequency polygons). In their expression, both absolute values as well as class ranges were used, determined according to the specific value range obtained. The study highlighted several aspects, namely: i) modal values (with the highest frequencies), ii) the limits of the variability ranges of the studied characters and iii) the specificity of each character of the wheat eco-types in the analyzed area.

Between the analyzed characters the correlations were established, with the help of which they were able to observe their tendencies within the studied ecotypes. The Excel program was used to express the values. The significance of correlation coefficients was obtained by comparing with the $r_{\max }$ values (Erna Weber, 1961) for the 5\%, 1\% and 0.1\% levels of transgression probabilities. 


\section{Current Trends in Natural Sciences}

Vol. 9, Issue 17, pp. 52-64, 2020

https://doi.org/10.47068/ctns.2020.v9i17.006

Current Trends in Natural Sciences (on-line)

ISSN: 2284-953X

ISSN-L: 2284-9521
Current Trends in Natural Sciences (CD-Rom)

ISSN: 2284-9521

ISSN-L: 2284-9521

In the statistical calculation of all the values obtained we used the variance analysis (Anova test) on the variation rows. Statistical parameters were calculated using the formulas: $\overline{\mathrm{a}}=\frac{\Sigma \mathrm{x}}{n}$, unde $\overline{\mathrm{a}}=$ the average of the determinations, and $\mathrm{x}=$ the determined values, $\mathrm{S}^{2}$ (variance) $=\frac{1}{n-1}\left[\Sigma x^{2}-\frac{(\Sigma x)^{2}}{n}\right], \mathrm{S}$ $($ standard error $)=\sqrt{\mathrm{S}^{2}}, \mathrm{~S} \%($ variation coefficient $)=\frac{S}{\mathrm{a}} 100$.

\section{RESULTS AND DISCUSSIONS}

Variability of wheat straw size. The strain or wheat straw consists of several internodes (usually 57) with increasing lengths to the top (ear). For winter wheat, the straw has lengths between 50(60) and $150 \mathrm{~cm}$. At harvest maturity, the stems are upright, with relatively low tall. The measurements showed that the winter wheat Phyton variety was between 48 and $68 \mathrm{~cm}$. The high frequency had $54-56 \mathrm{~cm}(31 \%)$ straw, followed by $57-59 \mathrm{~cm}$ (26\%). In the Foxyl variety straw had lengths of 48$68 \mathrm{~cm}$, of which 60-62 cm (25\%) dominated. Close to this were the 63-65 cm (20\%) (figure 1). Do to the these dimensions of wheat straw, the two forms of winter wheat are considered as new, evolved, intensive and adapted (figure 2).

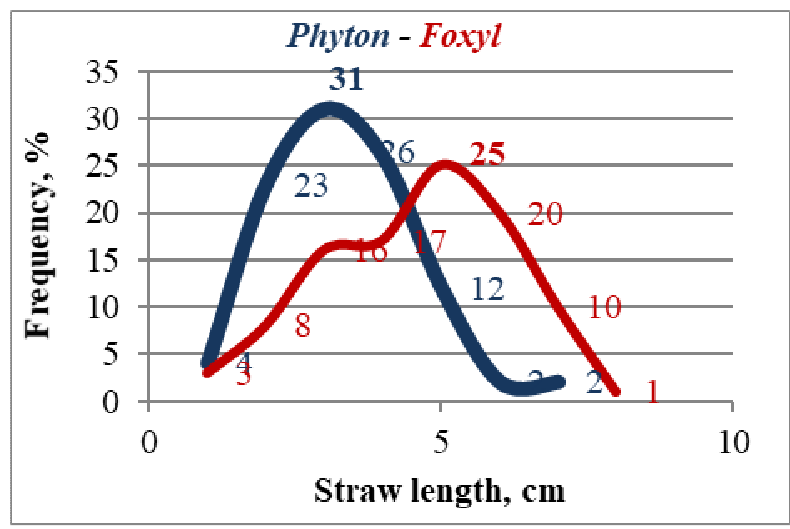

Figure 1. The frequencies of straw length

Limits: 48-50 51-53 $\underline{\mathbf{5 4 - 5 6}}$ 57-59 60-62 63-65 66-68 Limits: 48-50 51-53 54-56 57-59 0-62 63-65 66-68 >68

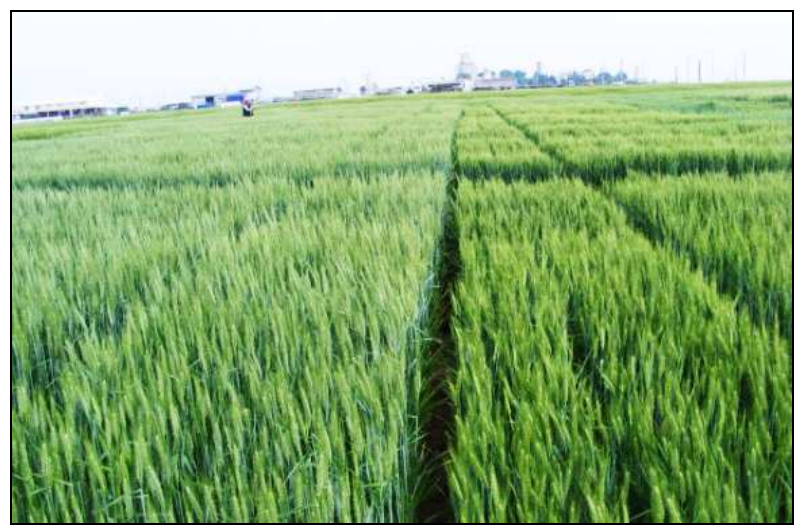

Figure 2. Foxyl-left and Phyton-right 
From the straw internodes were made length measurements for the last three- those under the ear. The lower internode (the third at the top) had lengths between 6 and $13 \mathrm{~cm}$ for the Phyton. The higher frequency was $10 \mathrm{~cm}(25 \%)$, followed by $11 \mathrm{~cm}(22 \%)$. The wheat Foxyl ranged in length from 8 to $15 \mathrm{~cm}$, with a modal value of $11 \mathrm{~cm} \mathrm{(35 \% ),} \mathrm{followed} \mathrm{closely} \mathrm{by} 12 \mathrm{~cm}$ (34\%) (figure 3). The diameter/ thickness of the basal internode was between 2.5 to $4.0 \mathrm{~mm}$ in Phyton and 2.3-3.8 $\mathrm{mm}$ in the case of the Foxyl (figure 4). The dominated segments were 3.1-3.2 $\mathrm{mm}$ in both shapes: $28 \%$ and $41 \%$ respectively.

The sub-apical internode had longer lengths of 17 to $21 \mathrm{~cm}$ in the Phyton variety and 14-23 cm in the Foxyl variety (figure 5). Higher frequencies had internodes of $20 \mathrm{~cm}(43 \%)$ in the first case and $19 \mathrm{~cm}(31 \%)$ in the second case. The internode under the spike (apical) is usually the longest. In the case of these forms were found dimensions close to those of the sub-apical internode. Thus, it ranged between 18 and $29 \mathrm{~cm}$ in the Phyton and 14-31 cm in the Foxyl. The highest frequencies were $22-25 \mathrm{~cm}$ in first wheat variety (36\%), and $20-21 \mathrm{~cm}$ in second wheat variety (33\%) (figure 6).

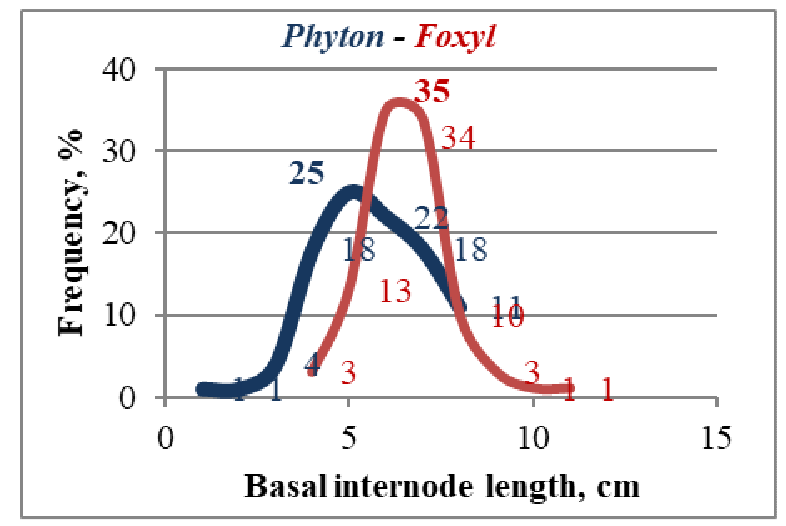

Figure 3. Frequencies of basal internode length Values: $6789 \underline{\mathbf{1 0}} 111213$

Values: $8910 \underline{11} \overline{12} 131415>15$

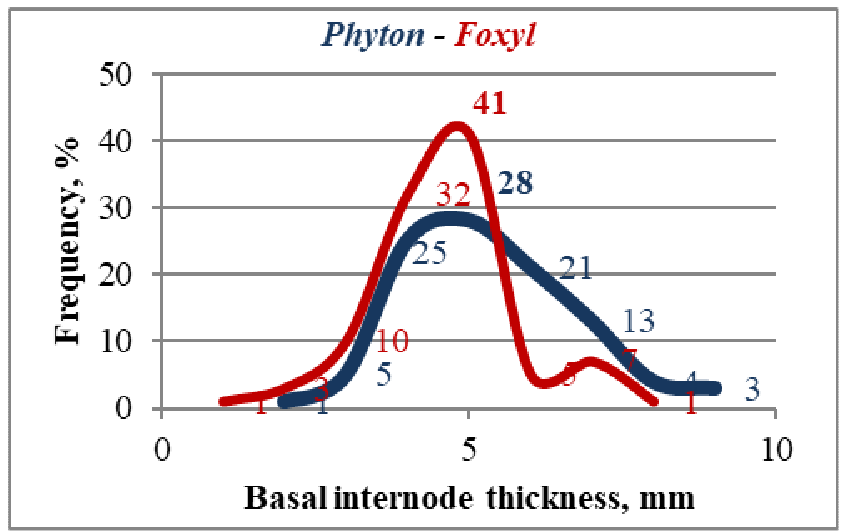

Figure 4. Frequencies of basal internode thickness Limits: 2.5-2.6 2.7-2.8 2.9-3.0 $\underline{\underline{\mathbf{3 . 1}-3.2}}$ 3.3-3.4 3.5-3.6 3.7-3.8 3.9-4.0

Limits: 2.3-2.4 2.5-2.6 2.7-2.8 2.9-3.0 $\underline{\text { 3.1-3.2 }}$ $3.3-3.43 .5-3.63 .7-3.8$ 


\section{Current Trends in Natural Sciences}

Vol. 9, Issue 17, pp. 52-64, 2020

https://doi.org/10.47068/ctns.2020.v9i17.006

Current Trends in Natural Sciences (on-line)

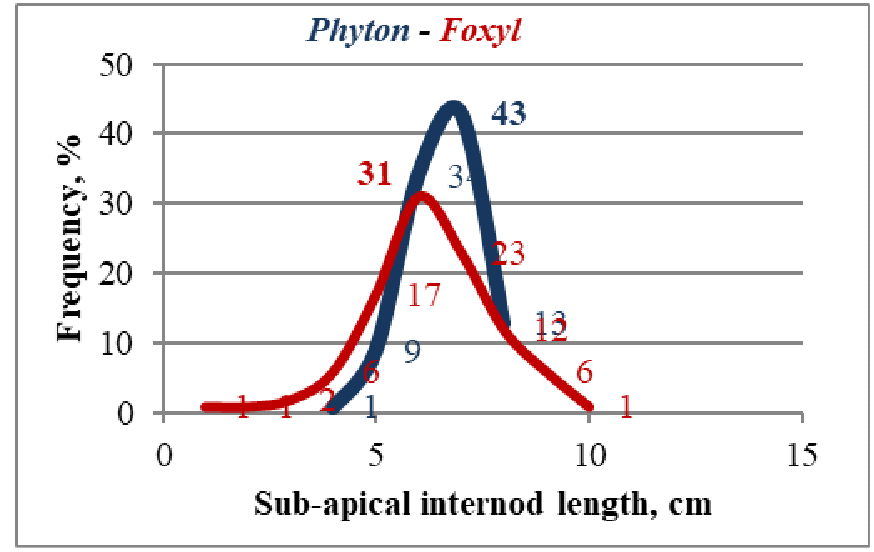

Figure 5. Frequencies of sub-apical internode length Values: $171819 \underline{\mathbf{2 0}} 21$

Values: $1415161718 \underline{\mathbf{1 9}} 20212223$

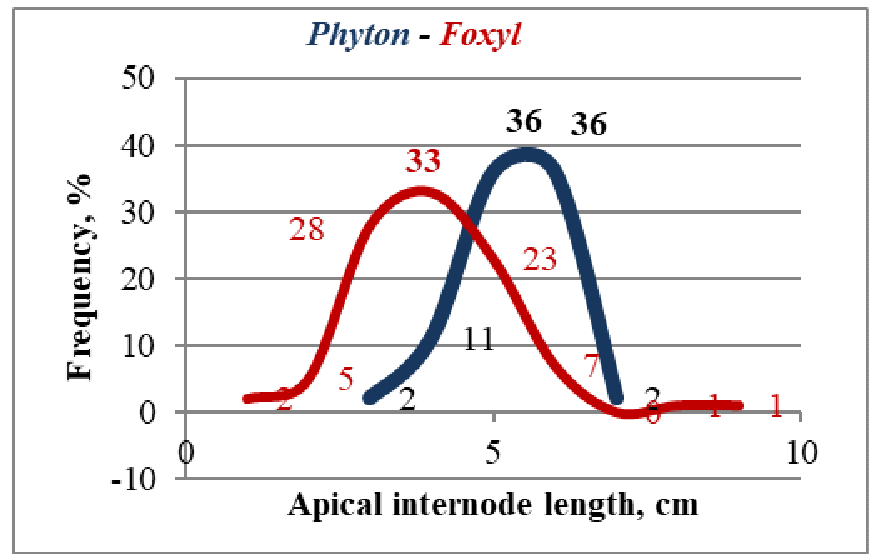

Figure 6. Frequencies of apical internode length

Limits:18-19 20-21, 22-23 24-25 26-27, 28-29

Limits: 14-15 16-17 18-19 20-21 22-23 24-25 26-27 28-29 30-31

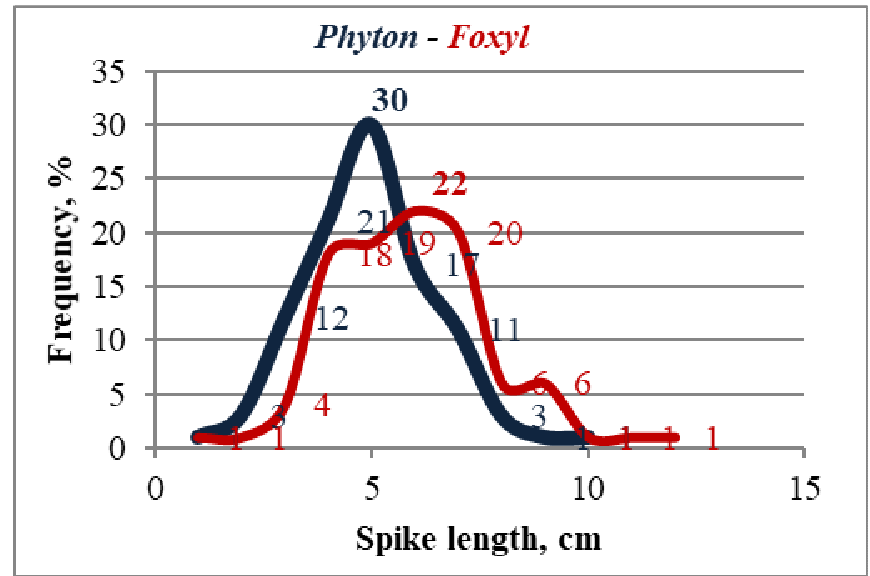

Figure 7. Frequencies of spike length

Limits: 5.7-6.0 6.1-6.4 6.5-6.8 6.9-7.2 7.3-7.6 7.7-8.0 8.1-8.4

$8.5-8.8$ 8.9-9.2 9.3-9.6

Limits: 5.7-6.0 6.1-6.4 6.5-6.8 6.9-7.2 7.3-7.5 7.7-8.0 8.1-8.4

8.5-8.8 8.9-9.2 9.3-9.6 9.7-10.0 10.1-10.4 
Current Trends in Natural Sciences

Vol. 9, Issue 17, pp. 52-64, 2020

https://doi.org/10.47068/ctns.2020.v9i17.006

Current Trends in Natural Sciences (on-line)

ISSN: 2284-953X

ISSN-L: 2284-9521
Current Trends in Natural Sciences (CD-Rom)

ISSN: 2284-9521

ISSN-L: 2284-9521

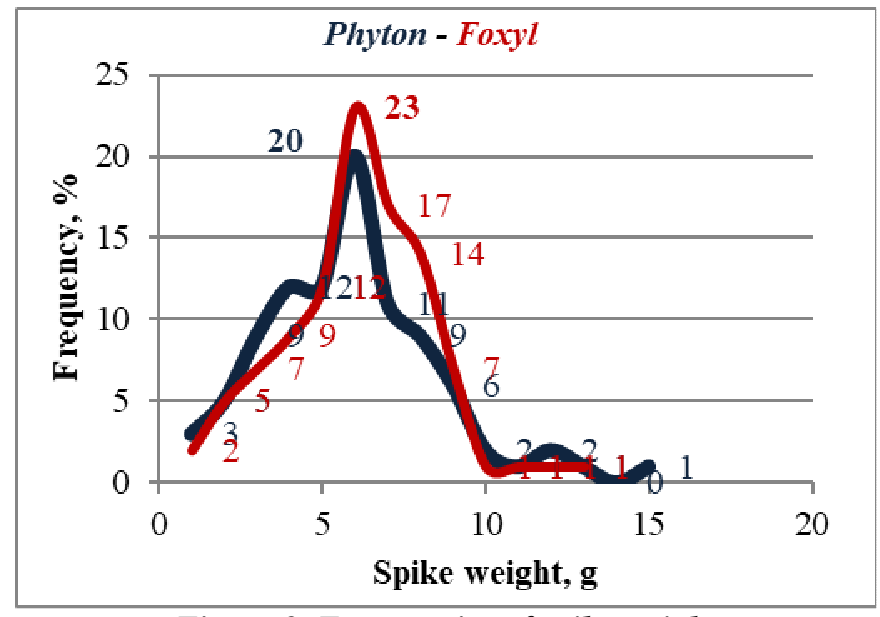

Figure 8. Frequencies of spike weight

Limits: 1.11-1.3 1.31-1.5 1.51-1.7 1.71-1.9 1.91-2.1 2.11-2.3 2.31-2.5 2.51-2.7 2.71-2.9 2.91-3.1 3.11-3.3 3.31-3.5 3.51-3.7 3.71-3.9 3.91-4.1 Limits: $1.11-1.3$ 1.31-1.5 1.51-1.7 1.71-1.9 1.91-2.1 $\underline{\mathbf{2 . 1 1}-2.3}$ 2.31-2.5 2.51-2.7 2.71-2.9 2.91-3.1 3.11-3.3 3.31-3.5 3.51-3.7

Variability of wheat spikes. The appearance and size of the spike of the two wheat forms were specifically influenced by the zonal crop system. Thus, the length of the spike oscillated between 5.7 and $9.6 \mathrm{~cm}$ in the Phyton form, and between 5.7 and $10.4 \mathrm{~cm}$ in the Foxyl form. The lengths of $7.3-7.6 \mathrm{~cm}(30 \%)$ were dominated in the first case and 7.7-8.0 $\mathrm{cm}(25 \% 0$ in the second case (figure 7). The spike/ear weight was between $1.11 \mathrm{~g}$ and $4.1 \mathrm{~g}$ for the Phyton and between 1.11 and $3.7 \mathrm{~g}$ for the Foxyl (figure 8). The spikes weighted between $2.11 \mathrm{~g}$ and $2.3 \mathrm{~g}$ in both forms: $20 \%$ modal value for Phyton variety and $23 \%$ for Foxyl variety.

The number of spikelets in a spike oscillated for both shapes between 11 and 21 (figure 9). The spikes were dominated by 16 spikelets (37\%) at the Phyton form and those with 17 spikelets in the Foxyl form (26\%). The spikelets glume also had similar lengths in both shapes, ranging from 6 to $10 \mathrm{~mm}$ (figure 10). In the case of the Phyton variety, glumes of 8-8.3 mm were dominated (50\%), and in Foxyl dominated glumes of 8.8-9.1 mm (43\%).

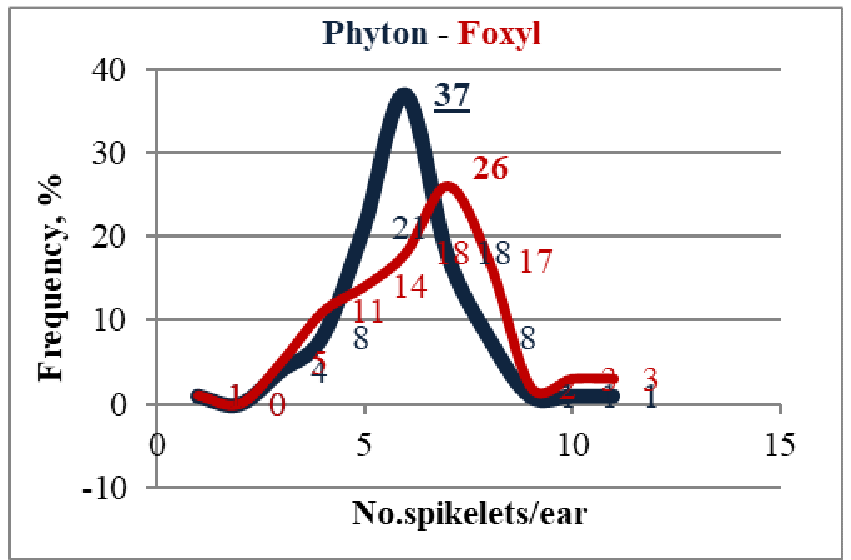

Fig. 9. Frequencies of spikelets no/ear

Values: $1112131415 \underline{16} 1718192021$

Values: $1112131415 \underline{16} \underline{\mathbf{1 7}} 18192021$ 
Current Trends in Natural Sciences

Vol. 9, Issue 17, pp. 52-64, 2020

https://doi.org/10.47068/ctns.2020.v9i17.006

Current Trends in Natural Sciences (on-line)

ISSN: 2284-953X

ISSN-L: 2284-9521
Current Trends in Natural Sciences (CD-Rom)

ISSN: 2284-9521

ISSN-L: 2284-9521

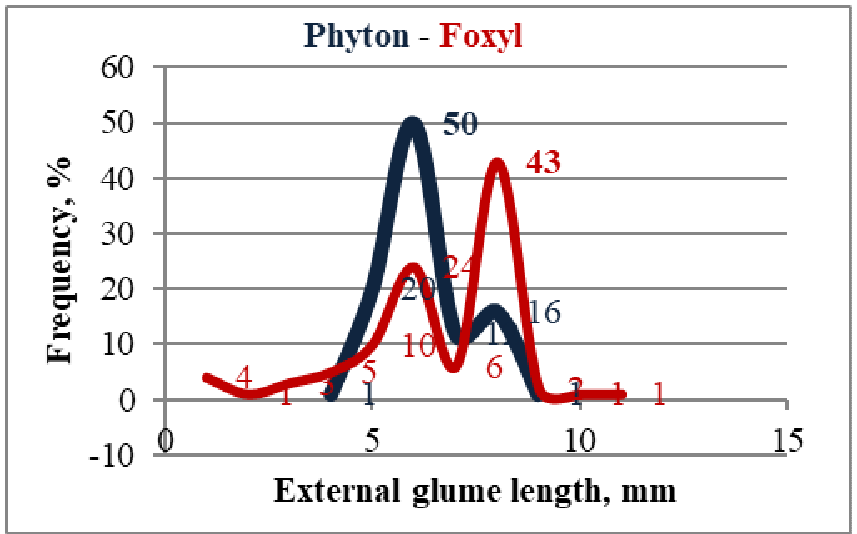

Fig. 10. Frequencies of glume length

Limits: 6-6.3 6.4-6.7 6.8-7.1 7.2-7.5 7.6-7.9 $\underline{\text { 8-8.3 }}$

8.4-8.7 8.8-9.1 9.2-9.5 9.6-9.9 10

Limits: 6-6.3 6.4-6.7 6.8-7.1 7.2-7.5 7.6-7.9 8-8.3

8.4-8.7 8.8-9.1 9.2-9.5 9.6-9.9 10

The inferior palea/ lemma ranged from 7.4 to $14 \mathrm{~mm}$ Phyton wheat form and from 8 over $14 \mathrm{~mm}$ in wheat Foxyl cultivar/ variety (figure 11). The paleas dominated with 8.6-8.8 $\mathrm{mm}(27 \%)$ on the first shape and 9.8-10 $\mathrm{mm}(32 \%)$ on the second shape.

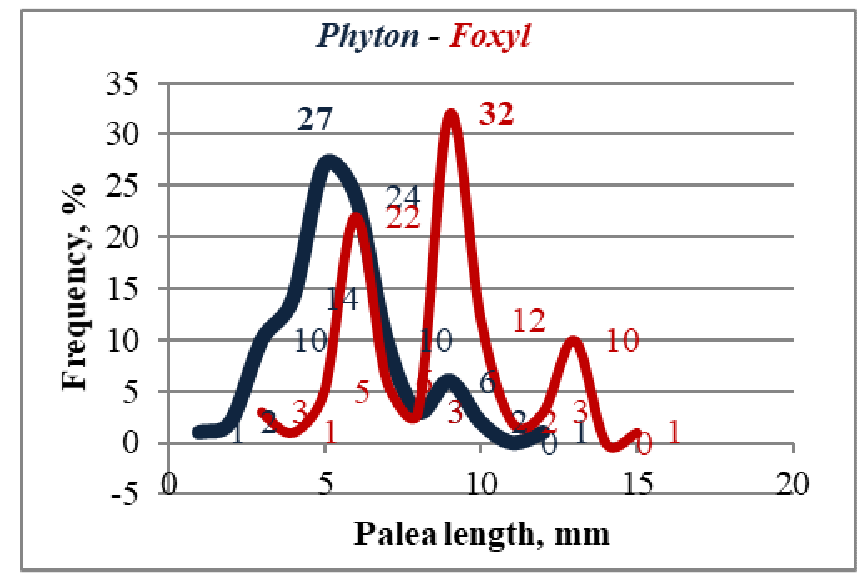

Figure 11. Frequencies of palea length

Limits: 7.4-7.6 7.7-7.9 8-8.2 8.3-8.5 8.6-8.8 8.9-9.19.2-9.4 9.5-9.7

9.8-10 10.1-10.3 10.4-10.6 10.7-10.9 11-11.2 11.3-11.4 >11.4

Limits: 8-8.2 8.3-8.5 8.6-8.8 8.9-9.19.2-9.4 9.5-9.7 $\underline{\text { 9.8-10 }}$

$10.1-10.3$ 10.4-10.6 10.7-10.9 11-11.2 11.3-11.4 >11.4

Another character of the spike is the length of the awns. Both forms being awned, their dimensions were specific to each one. The Phyton form had awn with lengths between 5.5 and $9.4 \mathrm{~mm}$ - those dominated by 7-7.4 mm (33\%). The Foxyl form had awns of between 4 and $6.9 \mathrm{~mm}$ and dominated those with 5-5.4 $\mathrm{mm}(82 \%)$ (figure 12).

Variability of wheat grains. It was found that each variety has characteristic aspects of the grains (Eira and Caldas, 2000). In the case of the Phyton form, the number of grains in a spike ranged from 30 to over 70. The higher frequency had the ears with 50-55 grains (38\%). The number of grains in 
Vol. 9, Issue 17, pp. 52-64, 2020

https://doi.org/10.47068/ctns.2020.v9i17.006

Current Trends in Natural Sciences (on-line)

ISSN: 2284-953X

Current Trends in Natural Sciences (CD-Rom)

ISSN: $2284-9521$

ISSN-L: 2284-9521 ISSN-L: 2284-9521

the Foxyl was between 15 and 64. The highest frequency was obtained in the range 35-39 (34\%) (figure 13).

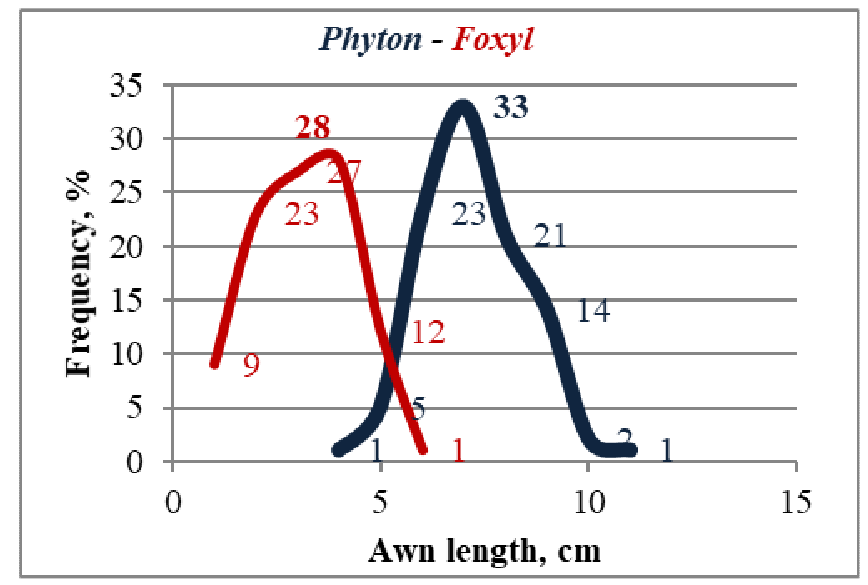

Figure 12. Frequencies of awn length

Limits: 5.5-5.9 6-6.4 6.5-6.9 7-7.4 7.5-7.9 8-8.4 8.5-8.9 9-9.4

Limits: 4-4.4 4.5-4.9 $\underline{\mathbf{5 - 5 . 4}}$ 5.5-5.9 6-6.4 6.5-6.9

The weight of the beans/ grains formed in a spike had appropriate values ranging from $0.81 \mathrm{~g}$ to 2.9 $\mathrm{g}$ for the Phyton and between 0.61 and $3.3 \mathrm{~g}$ for the Foxyl. The highest frequency was obtained at weights of 1.71-1.9 $\mathrm{g} \mathrm{(22 \% )}$ in the first case and 1.51-1.7 $\mathrm{g} \mathrm{(20 \% )}$ in the second case (figure 14).

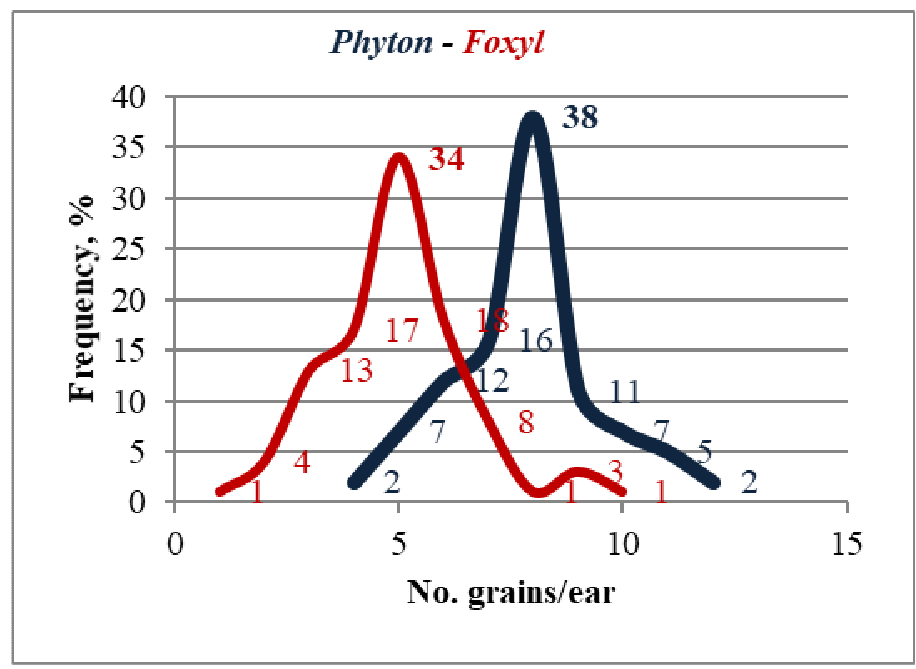

Figure 13. Frequencies of no. grains/ear

Limits: 30-34 35-39 40-44 45-49 $\underline{\mathbf{5 0 - 5 5}}$ 56-59 60-64 65-69 >70

Limits: 15-19 20-24 25-29 30-34 35-39 40-44 45-49 50-55 56-59 60-64

The grain sizes also had some characteristics. Thus, the length of the beans was in the range of 5.6$7.1 \mathrm{~mm}$, with a maximum at 6-6.1 $\mathrm{mm}(27 \%)$ in the Phyton form and the range between 5.8-7.3 $\mathrm{mm}$, with a maximum of 7-7.1 $\mathrm{mm}(35 \%)$ for the cultivated Foxyl form (figure 15). 
Vol. 9, Issue 17, pp. 52-64, 2020

https://doi.org/10.47068/ctns.2020.v9i17.006

Current Trends in Natural Sciences (on-line)

ISSN: 2284-953X

Current Trends in Natural Sciences (CD-Rom)

ISSN: $2284-9521$

ISSN-L: 2284-9521

ISSN-L: 2284-9521

The grain thickness ranged between 2.7 and $3.7 \mathrm{~mm}$, with a modal value of $3.1 \mathrm{~mm}(28 \%)$ for the Phyton and between 2.8-3.9 mm with the dominant range of 3.5-3.6 mm (16\%) for the Foxyl (figure 16).

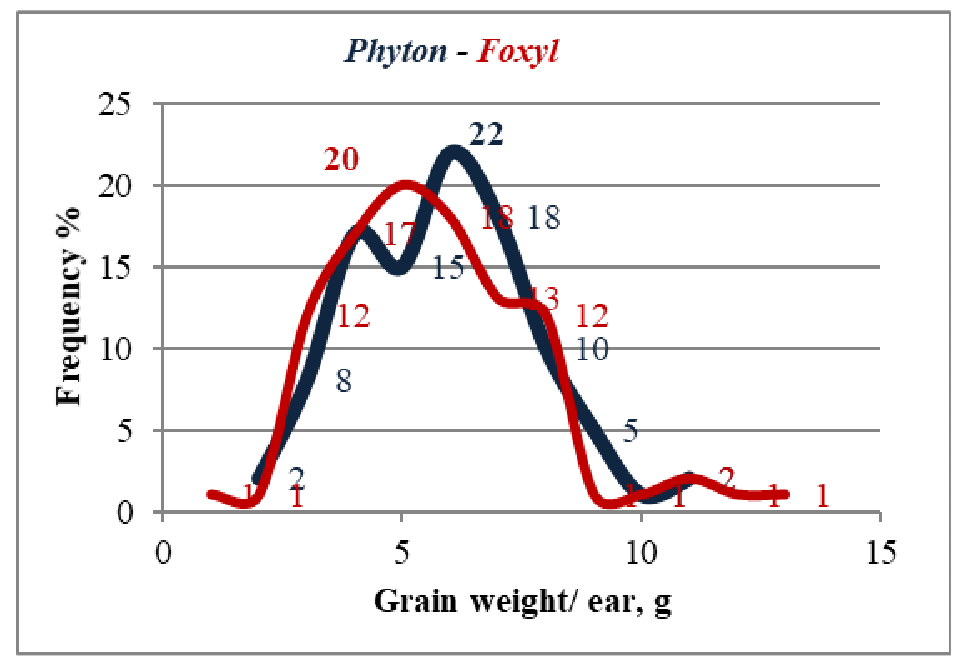

Figure 14. Frequencies of grain weight/ear

Limits: $0.81-1.01 .01-1.31 .31-1.51 .51-1.7 \underline{\text { 1.71-1.9 }}$

$1.91-2.12 .11-2.32 .31-2.52 .51-2.72 .71-2.9$

Limits: $0.61-0.80 .81-1.01 .01-1.31 .31-1.5$ 1.51-1.7 1.71-1.91.91-2.1

2.11-2.3 2.31-2.5 2.51-2.7 2.71-2.9 2.91-3.1 3.11-3.3

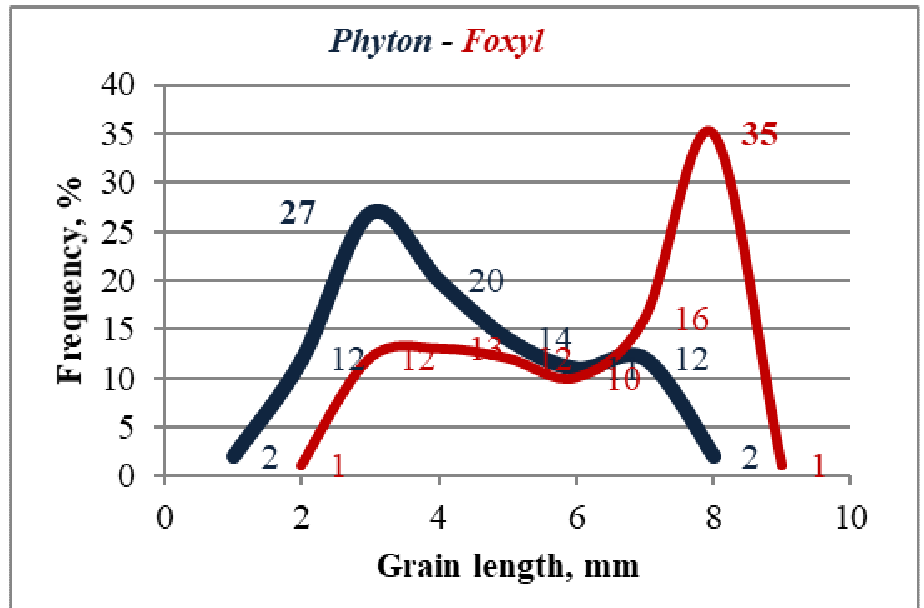

Figure 15. Frequencies of grain length

Limits: $5.6-5.7$ 5.8-5.9 6-6.1 6.2-6.3 6.4-6.5 6.6-6.7 6.8-6.9 7-7.1

Limits: 5.8-5.9 6-6.1 6.2-6.3 6.4-6.5 6.6-6.7 6.8-6.9 7-7.1 7.2-7.3

The thousand grains weight (TGW) has shown some differences. The extremes of this character were between 24 and $47.9 \mathrm{~g}$ in the Phyton form and between 33 and $56.9 \mathrm{~g}$ in the Foxyl form. The modal/ dominant values were also different. Thus, in the case of Phyton, the values of 33-35.9 g $(30 \%)$ were dominated, while in the Foxyl the grains with a mass of 45-50.9 $\mathrm{g}(28 \%)$ dominated (figure 17). The Phyton form was characterized by a larger number of grains/ear, but with a lower absolute mass (figure 18), while the analyzed Foxyl form had fewer grains into the ear but much heavier (figure 19). 


\section{Current Trends in Natural Sciences}

Vol. 9, Issue 17, pp. 52-64, 2020

https://doi.org/10.47068/ctns.2020.v9i17.006

Current Trends in Natural Sciences (on-line)

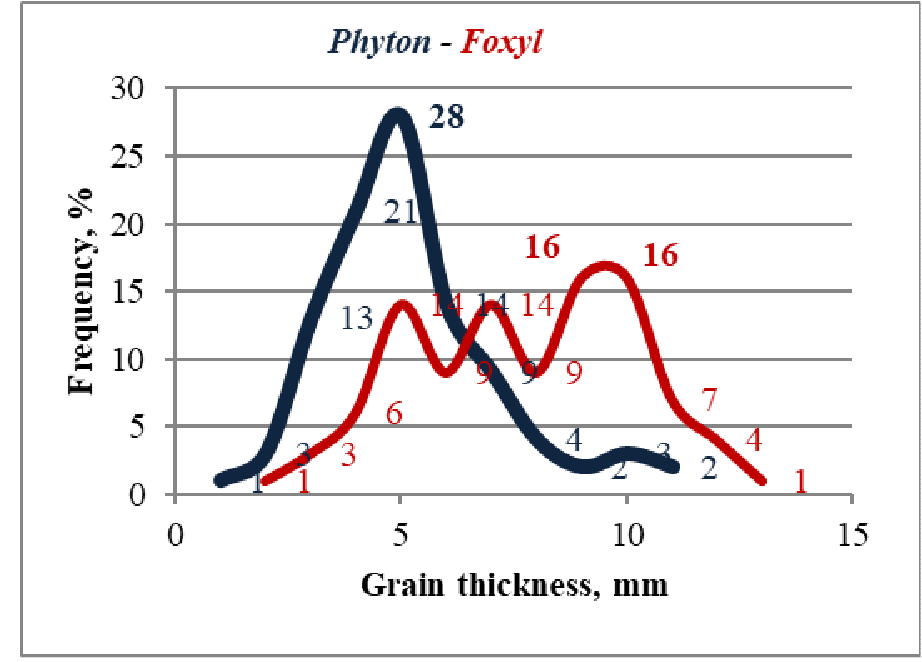

Figure 16. Frequencies of grain thickness

Limits: 2.72 .8 2.9 3.0 3.1 3.2 3.3 3.4 3.5 3.6 3.7

Limits: $2.82 .93 .03 .13 .23 .33 .4 \underline{\mathbf{3 . 5} \mathbf{3 . 6}} 3.73 .83 .9$

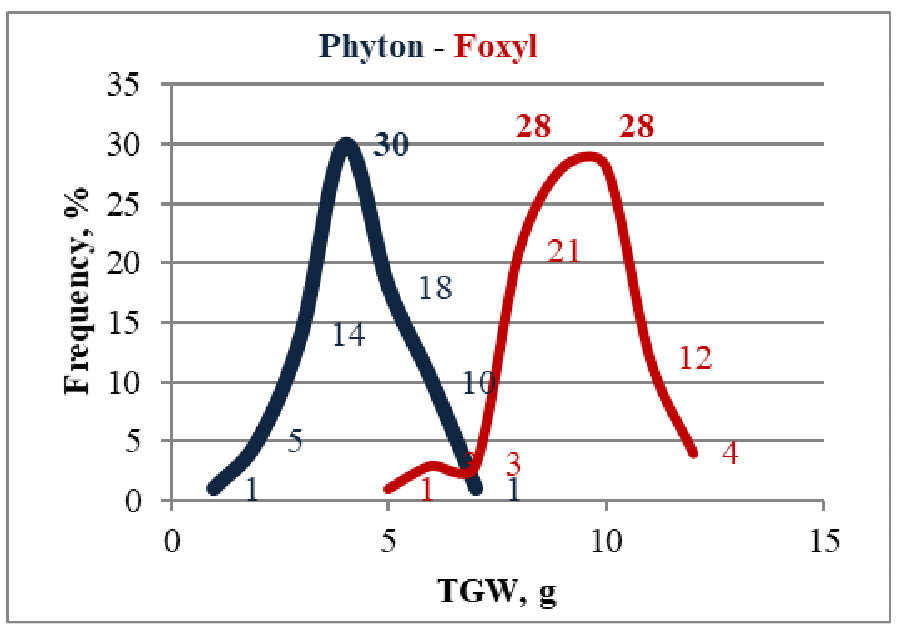

Figure 17. Frequencies of TGW evolution

Limits: <24 24-26.9 27-29.9 30-32.9 33-35.9 36-38.9 39-41.9 42-44.9 45-47.9

Limits: 33-35.9 36-38.9 39-41.9 42-44.9 45-47.9 48-50.9 51-53.9 54-56.9

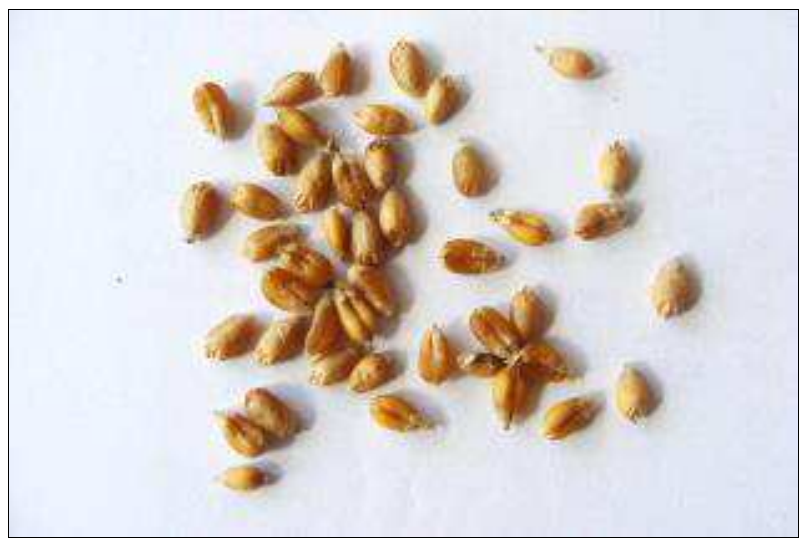

Fig. 18. Grains of Phyton variety 


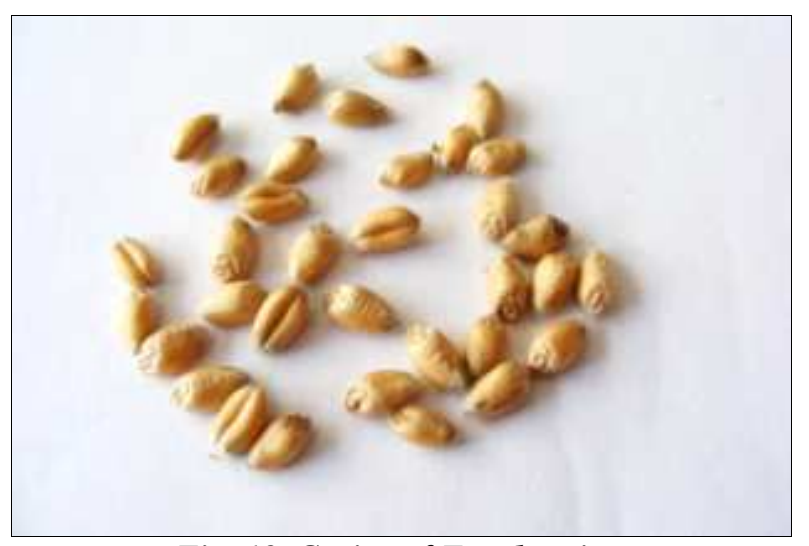

Fig. 19. Grains of Foxyl variety

Correlations between the main morphological characters. If we analyze the entire set of correlations of all the analyzed characters in Phyton wheat, we find specific situations. Thus, the total length of the straw and the length of the apical internode were insignificantly correlated with most of the analyzed characters. Instead, the characters of the ear (length, number of spikelets, number of grains) correlated very clearly between them. The mass of one thousand grains correlated very significantly with the grain weights in a spike and the grain thickness, both of which are the strong hybrid characters (table 1).

Table 1. Phyton, correlations between the main characters of plants

\begin{tabular}{|c|c|c|c|c|c|c|c|c|c|c|c|c|}
\hline Caracterul & $\begin{array}{c}\text { Straw } \\
\text { length, } \\
\text { cm }\end{array}$ & $\begin{array}{c}\text { Apical } \\
\text { internode } \\
\text { length, }\end{array}$ & $\begin{array}{c}\text { Ear } \\
\text { length, } \\
\text { cm }\end{array}$ & $\begin{array}{c}\text { Nr. } \\
\text { spikelets/ } \\
\text { ear }\end{array}$ & $\begin{array}{c}\text { Nr. } \\
\text { grains/ } \\
\text { ear }\end{array}$ & $\begin{array}{c}\text { Grain } \\
\text { weight/ } \\
\text { ear, } g\end{array}$ & $\begin{array}{c}\text { Glume } \\
\text { length, } \\
\text { mm }\end{array}$ & $\begin{array}{c}\text { Palea } \\
\text { length, } \\
\text { mm }\end{array}$ & $\begin{array}{l}\text { Awn } \\
\text { length, } \\
\text { cm }\end{array}$ & $\begin{array}{c}\text { Grain } \\
\text { length, } \\
\text { mm }\end{array}$ & $\begin{array}{c}\text { Grain } \\
\text { thickness, } \\
\text { mm }\end{array}$ & $\begin{array}{c}\text { TGW, } \\
\text { g }\end{array}$ \\
\hline Straw length,cm & 1 & .028 & -.168 & -.044 & .048 & .138 & -.062 & -.082 & -.122 & -.028 & .014 & .153 \\
\hline Apical int. length & & 1 & .096 & -.140 & -.137 & -.140 & .117 & .022 & .128 & .001 & -.093 & -.072 \\
\hline Ear length, cm & & & 1 & $.794 * * *$ & $.748 * * *$ & $.569 * * *$ & $.324 * * *$ & $.190 *$ & .181 & -.081 & .064 & .022 \\
\hline No. spikelets/ ear & & & & 1 & $.870 * * *$ & $.733 * * *$ & .149 & .065 & .136 & -.081 & .114 & .146 \\
\hline No. grains/ ear & & & & & 1 & $.805 * * *$ & $.261 * *$ & .107 & .062 & -.041 & .002 & .098 \\
\hline Grain weight/ ear & & & & & & 1 & .156 & .032 & .044 & .014 & $.282 * *$ & $.662 * * *$ \\
\hline Glume length, mm & & & & & & & 1 & $.293 * *$ & .062 & -.046 & -.003 & -.068 \\
\hline Palea length, mm & & & & & & & & 1 & -.001 & .117 & .022 & -.069 \\
\hline Awn length, mm & & & & & & & & & 1 & -.033 & -.129 & .003 \\
\hline Grain length, mm & & & & & & & & & & 1 & .073 & .112 \\
\hline Grain thickness, mm & & & & & & & & & & & 1 & $.492 * * *$ \\
\hline TGW, g & & & & & & & & & & & & 1 \\
\hline
\end{tabular}

Table 2. Foxyl, correlations between the main characters of plants

\begin{tabular}{|c|c|c|c|c|c|c|c|c|c|c|c|c|}
\hline Caracterul & $\begin{array}{l}\text { Straw } \\
\text { length, } \\
\text { cm }\end{array}$ & $\begin{array}{c}\text { Apical } \\
\text { internode } \\
\text { length, }\end{array}$ & $\begin{array}{c}\text { Ear } \\
\text { length, } \\
\text { cm }\end{array}$ & $\begin{array}{l}\text { Nr. } \\
\text { spikelets/ } \\
\text { ear }\end{array}$ & $\begin{array}{c}\text { Nr. } \\
\text { grains/ } \\
\text { ear }\end{array}$ & $\begin{array}{c}\text { Grain } \\
\text { weight/ } \\
\text { ear, } g\end{array}$ & $\begin{array}{c}\text { Glume } \\
\text { length, } \\
\text { mm }\end{array}$ & $\begin{array}{c}\text { Palea } \\
\text { length, } \\
\text { mm }\end{array}$ & $\begin{array}{l}\text { Awn } \\
\text { length, } \\
\text { cm }\end{array}$ & $\begin{array}{c}\text { Grain } \\
\text { length, } \\
\text { mm }\end{array}$ & $\begin{array}{c}\text { Grain } \\
\text { thickness, } \\
\text { mm }\end{array}$ & TGW, g \\
\hline Straw length,cm & 1 & $.257 * *$ & $-.256 * *$ & $.209 *$ & -.132 & -.103 & .006 & .020 & -.071 & -.002 & .109 & .010 \\
\hline Apical int. length & & 1 & -.164 & $-.294 * *$ & $-.240 *$ & $-.279 * *$ & -.121 & .022 & -.002 & .010 & -.145 & $-.239 *$ \\
\hline Ear length, cm & & & 1 & $.781 * * *$ & $.708 * * *$ &. $\mathbf{7 0 0} * * *$ & $.199 *$ & $.250 * *$ & $.235 *$ & .076 & -.108 & $.262 * *$ \\
\hline No. spikelets/ ear & & & & 1 & $.721 * * *$ & $.731 * * *$ & $.252 * *$ & .170 & $.250 * *$ & .113 & -.024 & $.308 * *$ \\
\hline No. grains/ ear & & & & & 1 & $.947 * * *$ & $.299 * *$ & $.304 * *$ & $.338 * * *$ & .145 & -.062 & $.216^{*}$ \\
\hline Grain weight/ ear & & & & & & 1 & $.355^{* * * *}$ & $.335 * * *$ & $.384 * * *$ & $.217 *$ & .076 & $.511 * * *$ \\
\hline Glume length, $\mathbf{m m}$ & & & & & & & 1 & $.398 * * *$ & .062 & .185 & .124 & $.244 *$ \\
\hline Palea length, mm & & & & & & & & 1 & .188 & .102 & .178 & .187 \\
\hline Awn length, mm & & & & & & & & & 1 & .167 & $.214 *$ & $.259 * *$ \\
\hline Grain length, mm & & & & & & & & & & 1 & .170 & $.285 * *$ \\
\hline $\begin{array}{c}\text { Grain thickness, } \\
\text { mm }\end{array}$ & & & & & & & & & & & 1 & $.420 * * *$ \\
\hline TGW, g & & & & & & & & & & & & 1 \\
\hline \multicolumn{13}{|c|}{ LSD $5 \%=0.19$} \\
\hline
\end{tabular}


In the case of Foxyl wheat, the correlations obtained were different. Thus, the length of the straw and the apical internode were negatively correlated at the level with the other analyzed characters. By doing so, this variety demonstrates less important dependence between the straw length and the productive features created. And in this variety there were very significant correlations between the characters of the spike and of the grains. The variety showed strong connections between TGWs with the length of ear, the number of spikelets in a spike, the number of spikelets in the spike, the grain/ ear weight, the length and thickness of the grain (table 2).

Statistical analysis of the morphological character variability in wheat varieties. The results obtained in the morphological analysis of some characters in winter wheat grown in the two forms, showed specific aspects. Thus, by comparing Phyton and Foxyl varieties, the length of the straw measured an average of $56 \mathrm{~cm}$ versus about $60 \mathrm{~cm}$. The base internode was $10.5 \mathrm{~cm}$ to $11.6 \mathrm{~cm}$, with an average thickness of $3.2 \mathrm{~mm}$ to $3.1 \mathrm{~mm}$. The sub-apical internode was $19.5 \mathrm{~cm}$ in length to $19.2 \mathrm{~cm}$, and the apical internode measured $23.4 \mathrm{~cm}$ versus $20.5 \mathrm{~cm}$.

Table 3. Statistical indices of wheat straw and ear

\begin{tabular}{|c|c|c|c|c|c|c|c|c|}
\hline \multirow[t]{2}{*}{ Indices } & \multirow{2}{*}{$\begin{array}{c}\text { Straw } \\
\text { length, } \\
\mathrm{cm}\end{array}$} & \multicolumn{2}{|c|}{ Basis internode, $\mathrm{cm}$} & \multirow{2}{*}{$\begin{array}{c}\text { Sub-apical } \\
\text { internode, } \\
\mathrm{cm}\end{array}$} & \multirow{2}{*}{$\begin{array}{c}\text { Apical } \\
\text { internode, } \\
\mathrm{cm}\end{array}$} & \multicolumn{2}{|c|}{ Spike (ear) } & \multirow{2}{*}{$\begin{array}{c}\text { Number } \\
\text { spikelets/ } \\
\text { ear }\end{array}$} \\
\hline & & $\begin{array}{l}\text { Length, } \\
\mathrm{cm}\end{array}$ & $\begin{array}{c}\text { Thickness, } \\
\text { mm }\end{array}$ & & & $\begin{array}{c}\text { Length, } \\
\mathrm{cm}\end{array}$ & $\begin{array}{c}\text { Weight, } \\
\mathrm{g}\end{array}$ & \\
\hline \multicolumn{9}{|c|}{ PHYTON } \\
\hline Media, $\bar{a}$ & 56.00 & 10.51 & 3.216 & 19.50 & 23.41 & 7.44 & 2.2143 & 15.92 \\
\hline Variance, $\mathrm{s}^{2}$ & 9.20 & 2.05 & 0.081 & 1.15 & 3.64 & 0.38 & 0.113 & 2.16 \\
\hline Std, error, s & 3.033 & 1.430 & 0.248 & 1.072 & 1.908 & 0.616 & 0.336 & 1.470 \\
\hline Variation coef, s\% & 5.42 & 13.61 & 1.21 & 5.50 & 8.15 & 8.28 & 15.17 & 9.23 \\
\hline \multicolumn{9}{|c|}{ FOXYL } \\
\hline Media, $\bar{a}$ & 59.68 & 11.56 & 3.060 & 19.16 & 20.53 & 7.81 & 2.16 & 16.37 \\
\hline Variance, $s^{2}$ & 22.22 & 7.12 & 0.052 & 5.86 & 5.989 & 0.544 & 0.270 & 3.528 \\
\hline Std, error, s & 4.714 & 2.668 & 0.228 & 2.421 & 2.447 & 0.738 & 0.520 & 1.878 \\
\hline Variation coef, s\% & 7.90 & 23.08 & 7.45 & 12.64 & 11.92 & 9.45 & 24.05 & 11.47 \\
\hline
\end{tabular}

Table 4. Statistical indices of wheat spikelets and grains

\begin{tabular}{|c|c|c|c|c|c|c|c|c|}
\hline \multirow[t]{2}{*}{ Indices } & \multirow{2}{*}{$\begin{array}{c}\text { GlumE } \\
\text { length, } \\
\mathrm{mm}\end{array}$} & \multirow{2}{*}{$\begin{array}{c}\text { Palea } \\
\text { length, } \\
\mathrm{mm}\end{array}$} & \multirow{2}{*}{$\begin{array}{c}\text { Awn } \\
\text { length, } \\
\mathrm{cm}\end{array}$} & \multirow{2}{*}{$\begin{array}{l}\text { Number. } \\
\text { grains/ ear }\end{array}$} & \multirow{2}{*}{$\begin{array}{c}\text { Grain } \\
\text { weight/ } \\
\text { ear,g }\end{array}$} & \multirow{2}{*}{$\begin{array}{c}\text { TGW, } \\
\text { g }\end{array}$} & \multicolumn{2}{|c|}{ Grains, mm } \\
\hline & & & & & & & Length & Thickness \\
\hline \multicolumn{9}{|c|}{ PHYTON } \\
\hline Media, $\bar{a}$ & 8.283 & 8.853 & 7.307 & 51.35 & 1.7684 & 34.357 & 6.281 & 3.119 \\
\hline Variance, $s^{2}$ & 0.158 & 0.610 & 0.374 & 83.77 & 0.152 & 21.653 & 0.129 & 0.038 \\
\hline Std, error, s & 0.397 & 0.781 & 0.612 & 9.153 & 0.390 & 4.653 & 0.360 & 0.195 \\
\hline Variation coef, s\% & 4.79 & 8.82 & 8.38 & 17.82 & 22.05 & 13.54 & 5.73 & 6.25 \\
\hline \multicolumn{9}{|c|}{ FOXYL } \\
\hline Media, $\bar{a}$ & 8.37 & 9.70 & 5.29 & 36.82 & 1.74 & 47.05 & 6.66 & 3.37 \\
\hline Variance, $s^{2}$ & 0.374 & 1.202 & 0.184 & 64.998 & 0.185 & 15.569 & 0.141 & 0.061 \\
\hline Std, error, s & 0.611 & 1.097 & 0.429 & 8.062 & 0.430 & 3.946 & 0.375 & 0.247 \\
\hline Variation coef, s\% & 7.30 & 11.31 & 8.11 & 21.90 & 24.73 & 8.39 & 5.64 & 7.34 \\
\hline
\end{tabular}

The length of spike was $7.44 \mathrm{~cm}$ to $7.81 \mathrm{~cm}$. The spike weight was $2.21 \mathrm{~g}$ versus $2.16 \mathrm{~g}$. The number of spikelets/ ear was on the one hand 15.9 for first form versus 16.4 for the analyzed second form (Foxyl) (table 3). Greater variability was the weight of the Foxyl spike, over $24 \%$.

Between two forms, the length of the awns was $8.3 \mathrm{~mm}$ (Phyton) versus $8.4 \mathrm{~mm}$ (Foxyl), that of the palea $8.9 \mathrm{~mm}$ versus $9.7 \mathrm{~mm}$, and the awn $7.3 \mathrm{~cm}$ vs. $5.3 \mathrm{~cm}$. In the order, the number of grains formed in a spike was 51.4 to 36.8 . The grain weight of a spike was $1.77 \mathrm{~g}$ at $1.74 \mathrm{~g}$. the grains had an average size of $6.28 / 3.12 \mathrm{~mm}$ versus $6.66 / 3.37 \mathrm{~mm}$. The mass of one thousand grains was 34.36 $\mathrm{g}$ at Phyton versus $47.05 \mathrm{~g}$ in the Foxyl (Table 4). Larger variability was found in the number of grains in a spike in the Foxyl variety. 


\section{CONCLUSIONS}

Morphological characters of winter wheat, studied in the both forms, had specific aspects. The choice of the two forms of winter wheat has been made due to the relatively close morphological similarity and the fact that they have recent genetic improvements, especially for the high productive potential, near to the good adaptability for actually climate changes.

By comparing the two forms, Phyton and Foxyl, the strain/ straw have average lengths of 56 to 60 $\mathrm{cm}$. At the plant's height, the basal internode contributed 11 to $12 \mathrm{~cm}$ in length and in thickness of 3.2 to $3.1 \mathrm{~mm}$, then sub-apical internode with 20 to $19 \mathrm{~cm}$ and the apical with 23 to $21 \mathrm{~cm}$. From the values obtained it is found the existence of low waist in both forms, a condition induced more and more in the improvement of the winter wheat to maximize the production.

The spike of 7.4 to $7.8 \mathrm{~cm}$ in length had a similar weight of about $2.2 \mathrm{~g}$. The number of spikelets was 15.9 versus 16.4. Spikelet pieces were: glumes of 8.3 to $8.4 \mathrm{~mm}$ in length, paleas 8.9 to 9.7 $\mathrm{mm}$, and awns 7.3 to $5.3 \mathrm{~cm}$ also in length. All these obtained data describe specific characters closely related between the two forms of winter wheat.

The number of grains in one spike was 51 to 37 by weight of 1.77 to $1.74 \mathrm{~g}$. The mass of one thousand grains ranged from 34 grams for Phyton and 47 grams in the case of Foxyl. The grains had the dimensions of 6.3 to $6.7 \mathrm{~mm}$ in length and 3.1 to $3.4 \mathrm{~mm}$ in thickness. The morphological characteristics of wheat grain show that Phyton grains have been formed a big number, but with an absolute smaller mass, while less grains have been formed in the Foxyl, but with much more absolute mass.

Between all the studied characters were established simple correlations, with some differences. The wheat straw and the apical internode have insignificantly correlated with other determinations for the Phyton and with some significant evidences for the Foxyl variety. Very positive links have been established between the ear/ spike components, demonstrating the high production potential of the two varieties tandem.

\section{REFERENCES}

Black, M.H., Halmer, P. (2006). The encyclopedia of seeds: science, technology and uses. CABI Wallingford, UK: 224.

Bonjean, A.P., William, J.A. (2001). The world wheat book: a history of wheat breeding. Excellent resource for $20^{\text {th }}$ contury plant breeding. Andover, 1-1131.

Bray, C.M., West, C.E. (2005). DNA repair mechanisms in plants: crucial sensors and effectors for the maintenance of genome integrity. New Phytologist, 168(3), 511- 528.

Brenchley, P., Spannagl, M., Pfeifer, M., Baker, G.L., d'Amore, R., Allen, A.M., McKenzie, N.,

Kramer, M., Kerhomov, A., Bolser, D., Kay, S., Waite, D., Trick, M., Bancroft, I., Gu, Y., Huo, N., Luo, M.C., Seghal, S., Gill, B., Klanian, S., Anderson, D., Kersey, P., Dvorak, J., McCombie, W.R., Hall, A., Bayer, K.F., Edwards, K.J., Bevan, M.W., Hall N. (2012). Analysis of the bread wheat genome using whole- genome shotgun sequencing. Nature, 491(7426), 705- 710.

Caligari, P.D.S., Brandham, P.E. (2001). Wheat taxonomy: the legacy of John Percival. Linnean Society, London, 3 , 190.

Eira, M.T.S., Caldas, L.S. (2000). Seed dormancy and germination as concurrent processes. Revista Brasilieiras Fisiologia Vegetal, 12, 85- 104.

Hopf, M., Zohary, D. (2000). Domestication of Plants in the Old World. The Origin and Spread of Cultivated Plants in West Asia, Europe and the Nile Valley. Oxford University Press, 33- 43.

Li, J., Wan, H.-S., Yang, W.-Y. (2014). Synthetic hexaploid wheat enhanced variation and adaptive

evolution of bread wheat in breeding processes. Journal of Systematics and Evolution, 52(6), 735-742.

Sabelli, P.H., Larkins, B.A. (2009). The Development of Endosperm in Grasses. Plant Physiology, 149(1), $14-26$.

Tester, M., Langridge, P. (2010). Breeding technologies to increase crop production in a changing world. $A A A S$ American Association for the Advancement of Science, Science, 327(5967), 818- 822. 